\title{
Effects of Calcium Source on Biochemical Properties of Microbial $\mathrm{CaCO}_{3}$ Precipitation
}

\author{
Jing Xu*, Yali Du, Zhengwu Jiang * and Anming She \\ Key Laboratory of Advanced Civil Engineering Materials, Tongji University, Ministry of Education, Shanghai, China
}

The biochemical properties of $\mathrm{CaCO}_{3}$ precipitation induced by Sporosarcina pasteurii, an ureolytic type microorganism, were investigated. Effects of calcium source on the precipitation process were examined, since calcium source plays a key role in microbiologically induced mineralization. Regardless of the calcium source type, three distinct stages in the precipitation process were identified by $\mathrm{Ca}^{2+}, \mathrm{NH}_{4}{ }^{+}, \mathrm{pH}$ and cell density monitoring. Compared with stage 1 and 3, stage 2 was considered as the most critical part since biotic $\mathrm{CaCO}_{3}$ precipitation occurs during this stage. Kinetics studies showed that the microbial $\mathrm{CaCO}_{3}$ precipitation rate for calcium lactate was over

OPEN ACCESS

Edited by:

Varenyam Achal,

East China Normal University, China

Reviewed by:

Jose M. Bruno-Barcena, North Carolina State University, USA Christopher L. Hemme,

University of Rhode Island, USA

${ }^{*}$ Correspondence: Jing Xu

0610060014@tongji.edu.cn; Zhengwu Jiang jzhw@tongji.edu.cn

Specialty section:

This article was submitted to Microbiotechnology, Ecotoxicology and Bioremediation,

a section of the journal

Frontiers in Microbiology

Received: 30 September 2015 Accepted: 17 November 2015 Published: 02 December 2015

Citation:

Xu J, Du Y, Jiang Z and She A (2015) Effects of Calcium Source on Biochemical Properties of Microbial $\mathrm{CaCO}_{3}$ Precipitation.

Front. Microbiol. 6:1366. doi: 10.3389/fmicb.2015.01366 twice of that for calcium nitrate, indicating that calcium lactate is more beneficial for the cell activity, which in turn determines urease production and $\mathrm{CaCO}_{3}$ precipitation. X-ray diffraction analysis confirmed the $\mathrm{CaCO}_{3}$ crystal as calcite, although scanning electron microscopy revealed a difference in crystal size and morphology if calcium source was different. The findings of this paper further suggest a promising application of microbiologically induced $\mathrm{CaCO}_{3}$ precipitation in remediation of surface and cracks of porous media, e.g., cement-based composites, particularly by using organic source of calcium lactate.

Keywords: S. pasteurii, ureolytic, bacterial $\mathrm{CaCO}_{3}$ precipitation, biochemistry, kinetics

\section{INTRODUCTION}

Since the phenomenon that $\mathrm{CaCO}_{3}$ precipitation could be induced by many soil bacteria was revealed (Boquet et al., 1973), research on microbial mineral plugging of porous media has been extensively carried out, especially on the application of bioremediation materials in civil engineering. Compared with traditional repair materials, which include cement grout, mortar, water glass, and epoxy resin, the bio-deposited materials are environmentally friendly and have a better compatibility with civil engineering materials, such as concrete and masonry (De Muynck et al., 2010; Wu et al., 2012). What is more to the point, self-repair can be achieved by using microbial induced deposition (Jonkers et al., 2010).

As a common process in nature, pores or fissures can be filled selectively by microorganisms which generate insoluble compounds inside or outside the cell wall (Ruiz et al., 1988). The mechanism of microbial deposition has been revealed and the feasibility of crack repairing in concrete by Bacillus pasteurii immobilized in polyurethane foam was verified (Stocks-Fischer et al., 1999; Bang et al., 2001; Bachmeier et al., 2002). It has been shown that the capillary water adsorption and gas permeability of concrete can be reduced effectively by surface treatment from microbiological mediated deposition, and the composition of bacterial culture medium has a 
TABLE 1 | Composition of liquid medium for each group.

\begin{tabular}{ll}
\hline Group & Composition \\
\hline $\mathrm{N}-\mathrm{B}$ & $\begin{array}{l}\text { Peptone } 5 \mathrm{~g} / \mathrm{L}, \text { Meat extract } 3 \mathrm{~g} / \mathrm{L}, \text { Urea } 20 \mathrm{~g} / \mathrm{L}, \\
\text { Calcium nitrate } 0.025 \mathrm{~mol} / \mathrm{L}, \text { Bacteria }\end{array}$ \\
$\mathrm{L}-\mathrm{B}$ & $\begin{array}{l}\text { Peptone } 5 \mathrm{~g} / \mathrm{L}, \text { Meat extract } 3 \mathrm{~g} / \mathrm{L}, \text { Urea } 20 \mathrm{~g} / \mathrm{L}, \\
\text { Calcium lactate } 0.025 \mathrm{~mol} / \mathrm{L}, \text { Bacteria }\end{array}$ \\
$\mathrm{N}-\mathrm{C}$ & Peptone $5 \mathrm{~g} / \mathrm{L}$, Meat extract $3 \mathrm{~g} / \mathrm{L}$, Urea $20 \mathrm{~g} / \mathrm{L}$, \\
& Calcium nitrate $0.025 \mathrm{~mol} / \mathrm{L}$ \\
$\mathrm{L}-\mathrm{C}$ & Peptone $5 \mathrm{~g} / \mathrm{L}$, Meat extract $3 \mathrm{~g} / \mathrm{L}$, Urea $20 \mathrm{~g} / \mathrm{L}$, \\
& Calcium lactate $0.025 \mathrm{~mol} / \mathrm{L}$ \\
\hline
\end{tabular}

significant impact on the morphology of $\mathrm{CaCO}_{3}$ (De Muynck et al., 2008a,b; Van Tittelboom et al., 2010; Achal et al., 2011; $\mathrm{Xu}$ et al., 2014). In recent years, bacterial induced deposition in using a non-ureolytic pathway has also been found (Jonkers et al., 2010). By mixing spores of these types of bacteria with fresh state concrete, self-healing of concrete cracks is expected since spores will germinate once cracking occurs and $\mathrm{CaCO}_{3}$ precipitation in the open cracks will be triggered by bacterial respiration (Wiktor and Jonkers, 2011; Wang et al., 2014a,b; Xu and Yao, 2014).

For the application of microbiologically induced precipitation in repairing, the primary issue would be the exploration of the biochemical process of the deposition. Since this process involves converting a soluble calcium source into insoluble $\mathrm{CaCO}_{3}$, the effect of the type of calcium source is critical. However, prior works concerning the influence of the type of calcium source on bacterial mineralization process are rare (De Muynck et al., 2008a). In this paper, the effect of two different types of calcium sources on the ureolytic microbiologically induced mineralization precipitation was investigated, which aims at providing guidance for further application.

\section{EXPERIMENTAL PROCEDURES}

\section{Bacterial Strains and Growth Conditions}

Sporosarcina pasteurii ATCC 11859 was used throughout. Bacteria were cultured in liquid media consisted of $5 \mathrm{~g}$ peptone, $3 \mathrm{~g}$ meat extract, and $20 \mathrm{~g}$ urea per liter of distilled water. Liquid media were sterilized by autoclaving for $20 \mathrm{~min}$ at $121^{\circ} \mathrm{C}$, then final $\mathrm{pH}$ was adjusted to be 9. Cultures were aerobically incubated at $30^{\circ} \mathrm{C}$ on a water-bath shaker operated at $100 \mathrm{rpm}$ for $24 \mathrm{~h}$. Growth was regularly checked quantitatively under optical microscopy by using a hemocytometer. At the end of the incubation, cultures were washed by repeated centrifugation and resuspension in fresh medium to harvest vegetative cells but to remove dissolved culture constituents and residues. Obtained suspensions were microscopically analyzed to quantify the number of cells present, and the suspension was subsequently kept at $4^{\circ} \mathrm{C}$ until further use.

\section{Microbiologically Induced $\mathrm{CaCO}_{3}$ Precipitation}

Calcium nitrate, instead of calcium chloride, was selected as a representative of inorganic calcium source since chloride ions

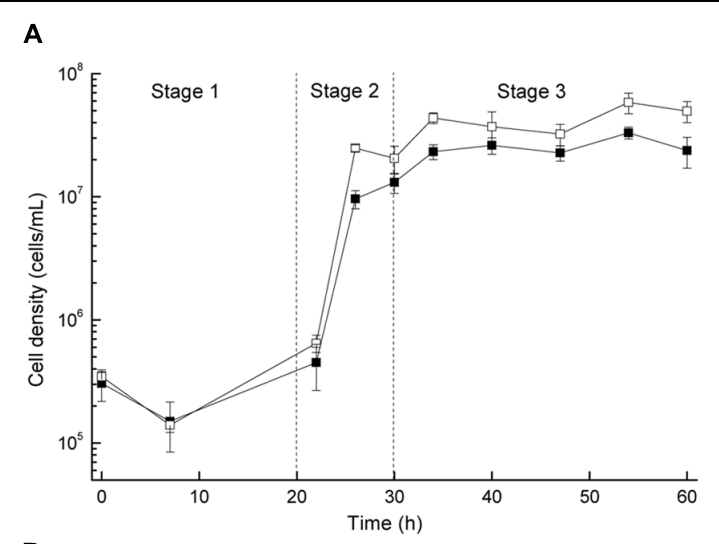

B

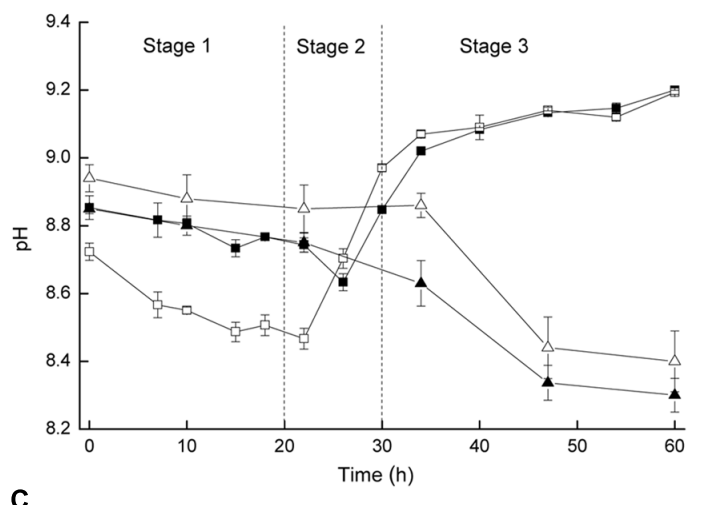

C
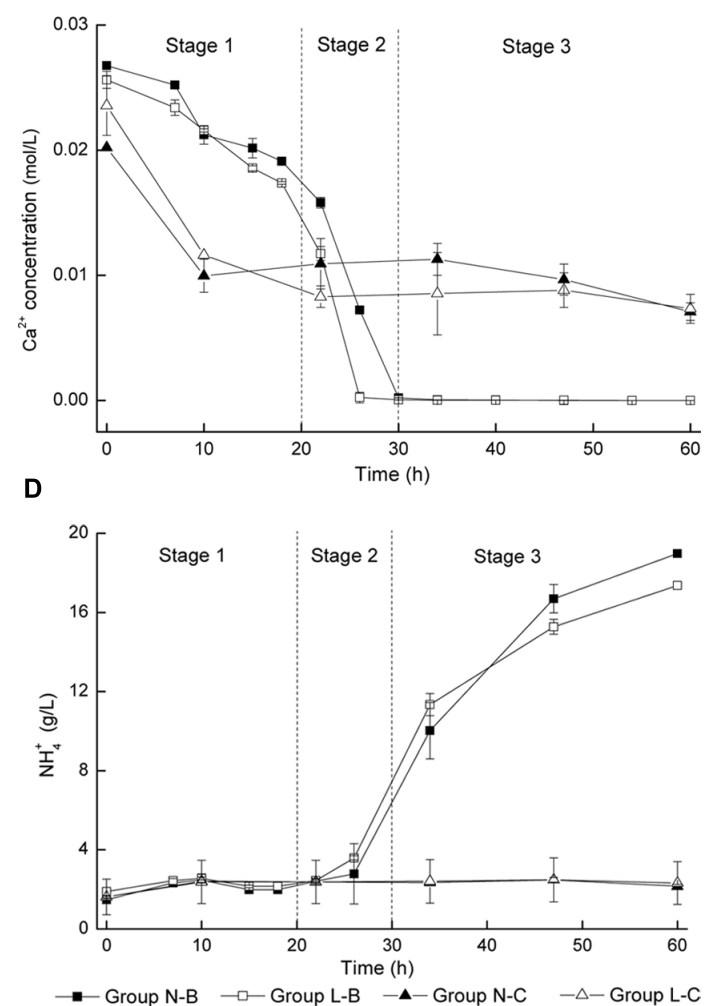

FIGURE 1 | Microbiologically induced $\mathrm{CaCO}_{3}$ precipitation: (A) Cell density; (B) pH values; (C) Soluble $\mathrm{Ca}^{2+}$ concentration; (D) $\mathrm{NH}_{4}{ }^{+}$ concentration. 

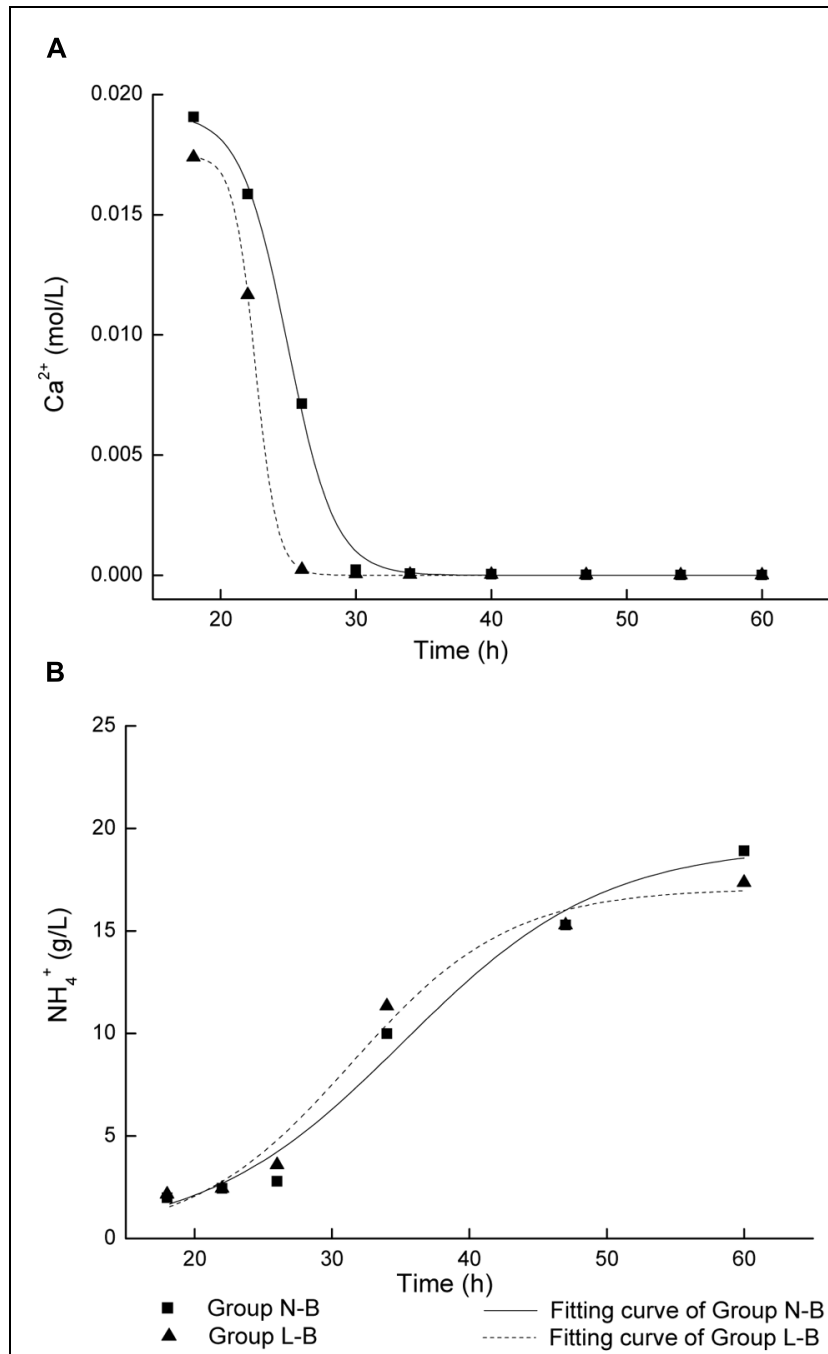

FIGURE 2 | Fitting of curves for microbiologically induced precipitation with live cells: (A) $\mathrm{CaCO}_{3}$ precipitation; (B) $\mathrm{NH}_{4}{ }^{+}$production.

may be detrimental for the concrete reinforcement. Calcium lactate, which is the most studied organic calcium-containing compound, was selected as a representative of organic calcium source. Groups without bacteria addition were set as control. The composition of liquid medium for each group is shown in Table 1, where letters of N, L, B, and C in group labels represent calcium nitrate, calcium lactate, bacteria, and control, respectively. Immediate abiotic $\mathrm{CaCO}_{3}$ precipitation usually occurs if the initial concentration of calcium ion is high in an alkaline environment, thus the concentration of calcium source was set to $0.025 \mathrm{~mol} / \mathrm{L}$.

For each group, triplicate sets of $250 \mathrm{~mL}$ Erlenmeyer flasks containing $80 \mathrm{~mL}$ of liquid medium were prepared. Each one was inoculated with live bacteria $\left(10^{5}\right.$ cells $\left./ \mathrm{mL}\right)$. Bacteria were grown at $30^{\circ} \mathrm{C}$ on the water-bath shaker operated at $100 \mathrm{rpm}$ for $60 \mathrm{~h}$. At regular intervals, three aliquots from each flask were taken to determine the $\mathrm{pH}$, the amount of soluble $\mathrm{Ca}^{2+}$, and the $\mathrm{NH}_{4}{ }^{+}$ concentration, respectively. For $\mathrm{pH}$ measurement, a Mettler

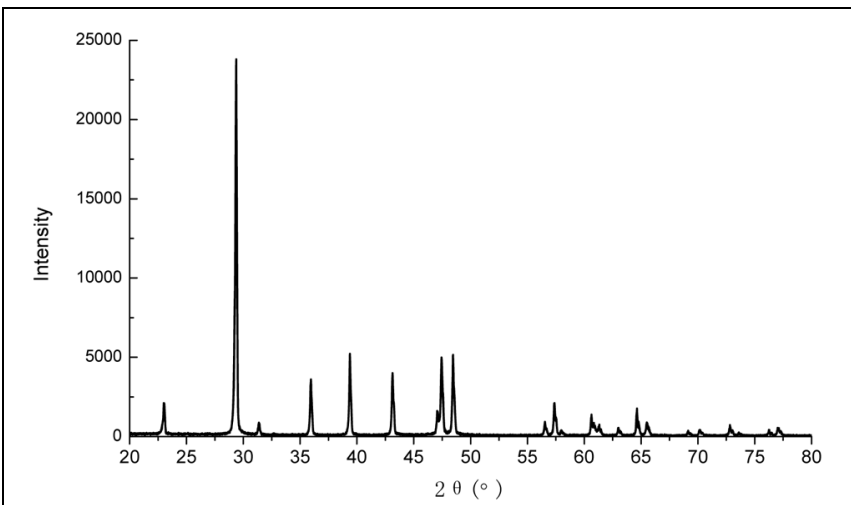

FIGURE 3 | X-ray diffraction (XRD) pattern of the precipitates.

Toledo $\mathrm{pH}$ probe was used. For soluble $\mathrm{Ca}^{2+}$ quantification, the liquid medium was centrifuged and the $\mathrm{Ca}^{2+}$ concentration in the supernatant was measured by the EDTA titration method (APHA, 1989). For $\mathrm{NH}_{4}{ }^{+}$concentration, an ammonia sensing probe was used. The cell density was measured simultaneously by plating colony-counting method, and the composition of the medium used was the same as the medium for culture growth.

\section{Characterization of Precipitates}

The mineralogy of precipitates was determined by powder X-ray diffraction (XRD) using a Rigaku D/max2550VB3+/PC diffractometer. The morphology of the precipitates was studied by scanning electron microscopy (SEM) using a Hitachi S-2360N. The composition of medium before and after precipitation was dried at $80^{\circ} \mathrm{C}$ and then analyzed by Fourier transform infrared spectroscopy (FT-IR) using a Bruker Hyperion 2000.

\section{RESULTS AND DISCUSSION}

\section{Biochemical Process of Microbiologically Induced $\mathrm{CaCO}_{3}$ Precipitation}

The growth of bacteria in the mineralized medium is shown in Figure 1A. The initial concentration of bacteria in medium was about $10^{5}$ cells $/ \mathrm{mL}$. In the first $22 \mathrm{~h}$ of induction period, the cell density showed a little increment of less than $2 \times 10^{5}$ cells $/ \mathrm{mL}$. The period of logarithmic growth appeared in $22-26 \mathrm{~h}$ and the cell density increased by nearly 100 times. It is observed that bacteria in medium with calcium lactate was more active than in medium with calcium nitrate, for the cell density of group L-B was always two times of that of group N-B. The control groups were not included since no strains were inoculated.

TABLE 2 | Rate constants of $\mathrm{CaCO}_{3}$ precipitation and ammonium ions production in different calcium source media.

\begin{tabular}{lcc}
\hline $\boldsymbol{k}\left(\mathbf{h}^{-\mathbf{1}}\right)$ & Calcium nitrate & Calcium lactate \\
\hline $\mathrm{CaCO}_{3}$ precipitation & 0.574 & 1.239 \\
Ammonia production & 0.137 & 0.174
\end{tabular}



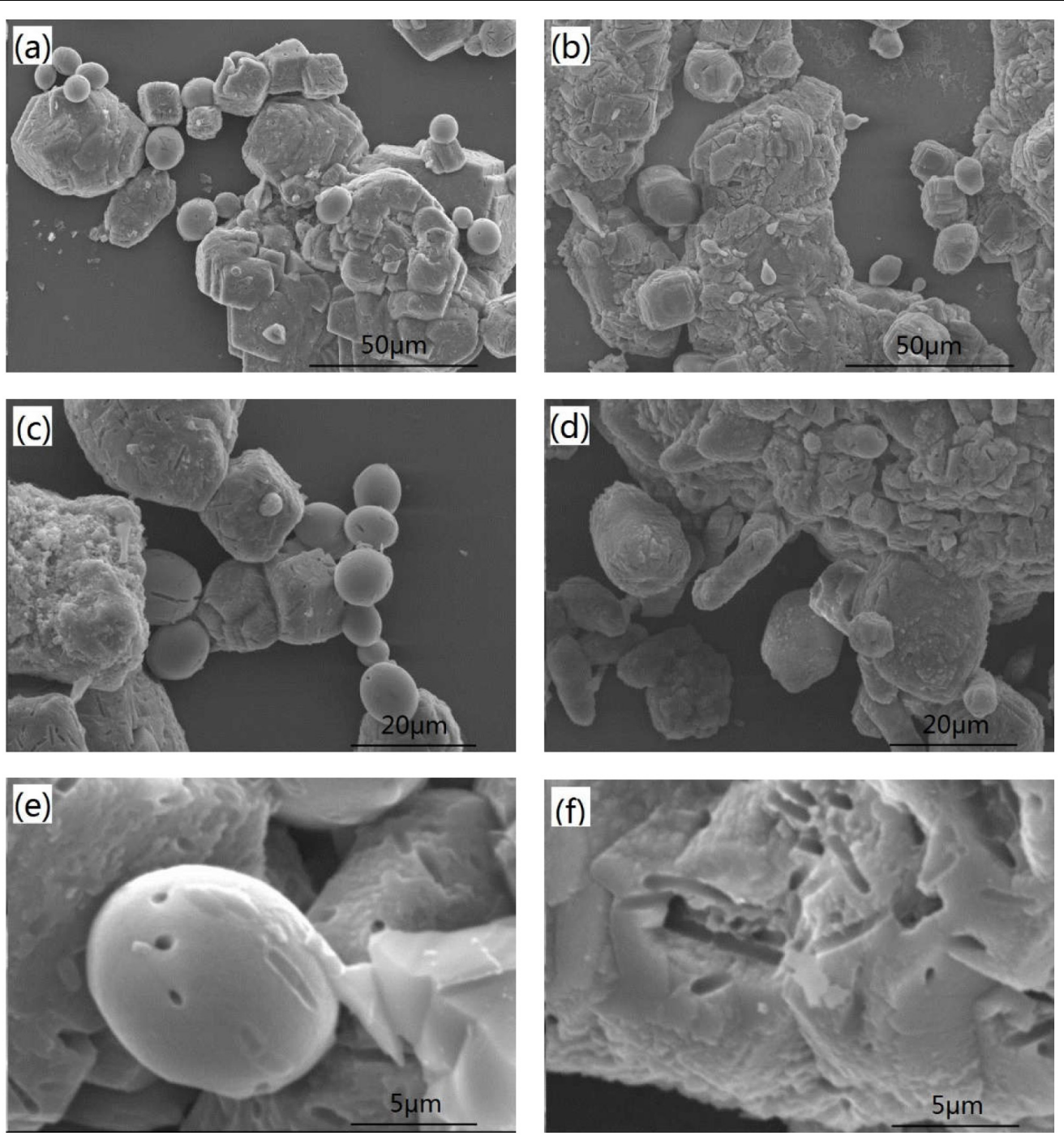

FIGURE 4 | Scanning electron microscopy (SEM) images of the precipitates from different calcium source: (a,c,e) calcium nitrate; (b,d) and (f) calcium lactate.

In Figure 1B, pH values of viable bacteria groups decreased for about 0.2 in the first $20-25 \mathrm{~h}$, then rose rapidly for about 0.5 in the next $5-10 \mathrm{~h}$, and finally kept steady. For the control groups, $\mathrm{pH}$ value variation less than 0.1 was observed in the first $30 \mathrm{~h}$, followed by a remarkable decline around 0.5 in the later period.

Figure 1C shows the evolution of soluble $\mathrm{Ca}^{2+}$ concentration. The $\mathrm{Ca}^{2+}$ concentration of viable bacteria groups decreased rapidly during $20-30 \mathrm{~h}$ for about $0.02 \mathrm{~mol} / \mathrm{L}$ until the free $\mathrm{Ca}^{2+}$ was completely converted into precipitates. For the control groups, $\mathrm{Ca}^{2+}$ concentration decreased for about $0.01 \mathrm{~mol} / \mathrm{L}$ in the first $10 \mathrm{~h}$ and then kept steady in the following period, indicating that free $\mathrm{Ca}^{2+}$ were not combined in the later stage.

In Figure 1D, the $\mathrm{NH}_{4}{ }^{+}$concentration of viable bacteria groups was nearly $3 \mathrm{~g} / \mathrm{L}$ in the first $22 \mathrm{~h}$, and then increased significantly to more than $10 \mathrm{~g} / \mathrm{L}$. In contrast, the $\mathrm{NH}_{4}{ }^{+}$ concentration for the control groups always kept constantly at $3 \mathrm{~g} / \mathrm{L}$.
The main objective of this paper is to explore the biochemical properties of bacterial induced mineralization, which would be very helpful for its application in structural remediation, particularly in concrete engineering. It was considered that the biochemical process of microbiologically induced $\mathrm{CaCO}_{3}$ precipitation consists of three distinct stages with similar pattern, regardless of the type of calcium source (Figure 1). Details for each stage is discussed as follows:

In the first stage, $\mathrm{pH}$ value and $\mathrm{Ca}^{2+}$ concentration dropped gradually while $\mathrm{NH}_{4}{ }^{+}$concentration and cell density were almost unchanged. The initial alkalinity of the medium was mainly caused by the decomposition of urea during sterilization. In general, $\mathrm{Ca}^{2+}$ ions are apt to precipitate in an alkaline environment, which in turn results in a decrease of $\mathrm{pH}$ value. It is interesting to note that a reduction of $0.012 \mathrm{~mol} / \mathrm{L}$ for $\mathrm{Ca}^{2+}$ occurred during this stage for both the groups with viable cells and control groups (Figure 1B), which indicates that abiotic 


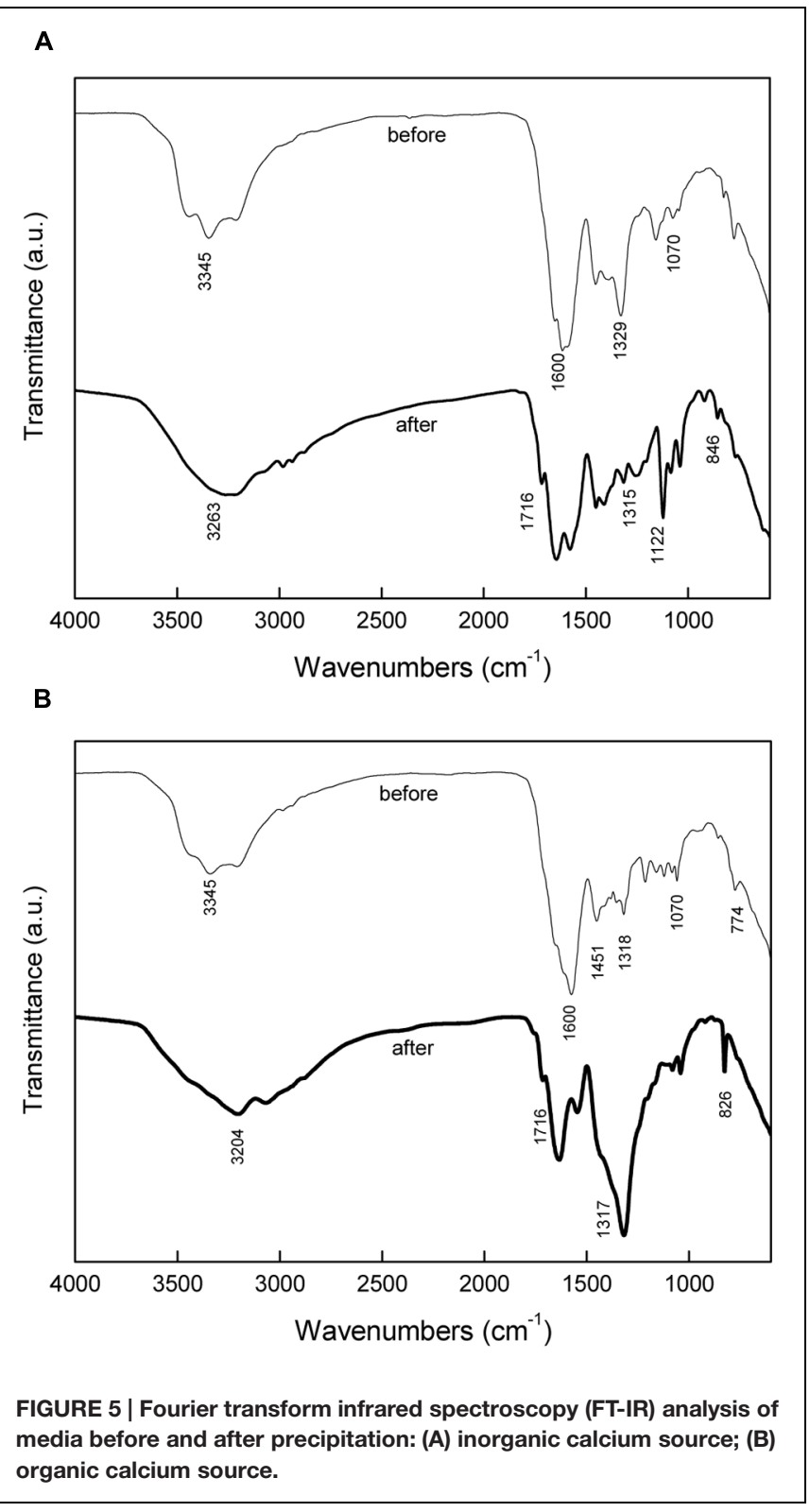

precipitation mainly contributes to the deposition of $\mathrm{CaCO}_{3}$ in this stage.

At the end of the second stage, the calcium sources were completely converted into $\mathrm{CaCO}_{3}$. The biological-chemical mechanism of this process can be expressed as follows

$$
\begin{aligned}
& \mathrm{CO}\left(\mathrm{NH}_{2}\right)_{2}+3 \mathrm{H}_{2} \mathrm{O} \stackrel{\text { Urease }}{\longrightarrow} 2 \mathrm{NH}_{4}^{+}+2 \mathrm{OH}^{-}+\mathrm{CO}_{2} \uparrow \\
& \mathrm{CO}_{2}+\mathrm{H}_{2} \mathrm{O} \leftrightarrow \mathrm{HCO}^{-}+\mathrm{H}^{+} \\
& \mathrm{HCO}^{-}+\mathrm{H}_{2} \mathrm{O} \leftrightarrow \mathrm{H}^{+}+\mathrm{CO}_{3}^{2-} \\
& \text { Cell- } \mathrm{Ca}^{2+}+\mathrm{CO}_{3}^{2-} \rightarrow \text { Cell-CaCO} \downarrow
\end{aligned}
$$

At this stage, the density of bacteria increased by two orders of magnitude, which corresponds to the logarithmic phase of bacterial growth. Urea was decomposed into $\mathrm{NH}_{3}$ and $\mathrm{CO}_{2}$ by urease, which was produced by bacteria. $\mathrm{pH}$ value increased rapidly due to the fact that the large amount of $\mathrm{NH}_{3}$ generated by decomposition of urea. An increase of $\mathrm{pH}$ value promoted the dissolution of $\mathrm{CO}_{2}$ and the hydrolysis reaction of $\mathrm{HCO}^{-}$, resulting in an increase of $\mathrm{CO}_{3}{ }^{2-}$ concentration. In the meantime, positively charged metal ions were bound on bacterial surfaces due to the presence of several negatively charged groups on the cell wall. Such bound metal ions (e.g., $\mathrm{Ca}^{2+}$ ) may subsequently react with anions (e.g., $\mathrm{CO}_{3}{ }^{2-}$ ) to form an insoluble salt (e.g., $\mathrm{CaCO}_{3}$ ) (Stocks-Fischer et al., 1999; Bang et al., 2010; De Muynck et al., 2010). Although the duration of stage 2 is short, it should be considered as a critical part in the whole process, and enzymatic hydrolysis by microorganisms is essential in this stage.

For the last stage, depletion of free $\mathrm{Ca}^{2+}$ was observed, while the bacteria density almost remained constant around $10^{7}$ cells/mL, because of the depletion of nutrients and an increased amount of harmful metabolite. $\mathrm{NH}_{3}$ and $\mathrm{CO}_{2}$ were continuously released due to sustained decomposition of urea. The increase of $\mathrm{pH}$ value slowed down because the neutralization effect of $\mathrm{CO}_{2}$ with $\mathrm{NH}_{3}$.

\section{Kinetics of Biotic $\mathrm{CaCO}_{3}$ Precipitation}

As presented above, $\mathrm{CaCO}_{3}$ precipitation and ammonia production is correlated with cell growth. It could be noted that the initiation of biotic $\mathrm{CaCO}_{3}$ precipitation and ammonia production for the group L-B was earlier than that of group N-B (Figures 1B,D). In order to further study the effect of calcium source on the biochemical process, kinetics of biotic $\mathrm{CaCO}_{3}$ precipitation as well as ammonia production was examined. In Figure 2, curves corresponding to biotic $\mathrm{CaCO}_{3}$ precipitation (data in stage 1were excluded) were fitted by an exponential logistic equation (Marquardt, 1963)

$$
y=\frac{a}{1+e^{-k\left(x-x_{c}\right)}}
$$

where $x$ is time, $y$ is ion concentration, $a$ is the variation range of $y, x_{c}$ is the time when $\mathrm{d} y / \mathrm{d} x$ reaches the maximum value, $k$ is the rate constant. The $k$ values of $\mathrm{CaCO}_{3}$ precipitation and ammonia production were calculated from regression analysis, as shown in Table 2.

The rate constants in medium with calcium lactate are larger than that in medium with calcium nitrate. In particular, the $k$ value of $\mathrm{CaCO}_{3}$ precipitation in calcium lactate is over twice of that in calcium nitrate. It suggests that higher cell activity and faster biotic $\mathrm{CaCO}_{3}$ precipitation and ammonia production rate if organic source of calcium lactate was used, which could be due to the bacterial metabolic conversion of calcium lactate according to the following reaction (De Muynck et al., 2010):

$$
\mathrm{CaC}_{6} \mathrm{H}_{10} \mathrm{O}_{6}+6 \mathrm{O}_{2} \rightarrow \mathrm{CaCO}_{3} \downarrow+5 \mathrm{CO}_{2} \uparrow+5 \mathrm{H}_{2} \mathrm{O}
$$

Calcium lactate is not only the calcium source, but a kind of carbon source that provides additional nutrition for bacteria. Moreover, extra amounts of $\mathrm{CO}_{2}$ were released if calcium lactate was decomposed by bacterial metabolism. It was reported that other organic calcium compounds have similar bio-reaction 
(Jonkers, 2011). In this respect, organic calcium source seems more beneficial for microbial mediated $\mathrm{CaCO}_{3}$ precipitation. It is worth to mention that substantial calcium lactate can be obtained from dairy by-products, which can meet the requirements of a potential use of calcium lactate in the field.

\section{Analysis of Precipitates}

Calcite was precipitated in the liquid medium irrespective of the type of calcium source, as confirmed by XRD analysis (Figure 3). This is consistent with results of other researchers (Bang et al., 2001; De Muynck et al., 2008a).

Figure 4 shows SEM images of calcite precipitates from two kinds of calcium sources. Difference in morphology was observed from calcium nitrate to calcium lactate. The sediments from calcium nitrate are spherical and lamellar particles, with particle size less than $50 \mu \mathrm{m}$. In contrast, sediments from calcium lactate are mostly irregular compact lumps or rhombohedral crystals with relatively larger particle size. Imprints of $2-4 \mu \mathrm{m}$ long and $0.7 \mu \mathrm{m}$ wide were observed on the surface of crystals. These imprints are likely left by bacteria. Prior findings have already verified that bacterial cells can provide favorable conditions by acting as a nucleus for the formation of crystals (Stocks-Fischer et al., 1999; Bang et al., 2010).

Figure 5 shows the FT-IR spectra of medium with different calcium source before and after precipitation. For the medium before precipitation, the presence of urea was indicated by amino signature at 3345 and $1070 \mathrm{~cm}^{-1}$ and carboxide signature at $1600 \mathrm{~cm}^{-1}$. Calcium nitrate was identified by absorption peak at $1329 \mathrm{~cm}^{-1}$. Calcium lactate was identified by absorption bands at 1451,1318 , and $774 \mathrm{~cm}^{-1}$. For the medium with calcium nitrate after precipitation, a small broad hump at $3263 \mathrm{~cm}^{-1}$ and the absorption band $1315 \mathrm{~cm}^{-1}$ correspond to $\mathrm{NH}_{4}{ }^{+}$, while bands near $1716 \mathrm{~cm}^{-1}, 1122 \mathrm{~cm}^{-1}$, and $846 \mathrm{~cm}^{-1}$ indicate the presence of $\mathrm{CO}_{3}{ }^{2-}$. Bands corresponding to $\mathrm{NH}_{4}{ }^{+}$and $\mathrm{CO}_{3}{ }^{2-}$ were also detected for the medium with calcium lactate after precipitation. FT-IR spectra confirms that $\mathrm{NH}_{4}{ }^{+}$and $\mathrm{CO}_{3}{ }^{2-}$ were produced by bacterial metabolism.

Although calcite was obtained irrelevant to the type of calcium source, different crystal size and morphology were observed for calcium nitrate and calcium lactate. This is consistent with other findings showing that the type of calcium source has a significant impact on the crystallization process (De Muynck et al., 2008a).

\section{REFERENCES}

Achal, V., Mukherjee, A., and Reddy, M. S. (2011). Microbial concrete: way to enhance the durability of building structures. J. Mater. Civ. Eng. 23, 730-734. doi: 10.1061/(ASCE)MT.1943-5533.0000159

APHA (1989). Standard Methods for the Examination of Water and Wastewater, 17th Edn. Washington, DC: American Public Health Association.

Bachmeier, K. L., Williams, A. E., Warmington, J. R., and Bang, S. S. (2002). Urease activity in microbiologically-induced calcite precipitation. J. Biotechnol. 93, 171-181. doi: 10.1016/S0168-1656(01)00393-5

Bang, S. S., Galinat, J. K., and Ramakrishnan, V. (2001). Calcite precipitation induced by polyurethane-immobilized Bacillus pasteurii. Enzyme Microb. Technol. 28, 404-409. doi: 10.1016/S0141-0229(00)00348-3
The crystal growth can be inhibited or altered by the adsorption of organic or inorganic matters to specify crystallographic planes of the growing crystal (Rodriguez-Navarro et al., 2007). On the other hand, differences in crystal morphology could be due to the level of the actual urease activity, which correlates with the cell activity. It further confirms the kinetics results demonstrating that cell activity differs from inorganic calcium nitrate to organic calcium lactate. The influence of conditions other than calcium source type, such as $\mathrm{pH}$, temperature, composition and concentration of nutrients on the morphology of precipitates, are worthy of further research. The influence of morphology and crystal size of on the properties of $\mathrm{CaCO}_{3}$ precipitates also needs assessment in civil engineering remediation application.

\section{CONCLUSION}

The biochemical investigations revealed that the microbiologically induced $\mathrm{CaCO}_{3}$ precipitation consists of three distinct stages and is independent of calcium source. The rate of precipitation for calcium lactate was over twice of that for calcium nitrate, indicating that organic source of calcium lactate may be more beneficial for the cell activity, which directly related to urease production and $\mathrm{CaCO}_{3}$ deposition. The $\mathrm{CaCO}_{3}$ crystal were identified as calcite, although the morphology varied if the type of calcium source was different. It also confirmed that bacterial cells acted as nucleation sites for crystal formation and growth.

\section{AUTHOR CONTRIBUTIONS}

JX, corresponding author and the main contributor of the paper; YD, contribute to the main part of experimental work of the paper; ZJ, provide some ideas and part of funding to the work; AS, provide some ideas and part of testing of the paper.

\section{ACKNOWLEDGMENTS}

The authors would like to acknowledge the financial support for this study from the National Natural Science Foundation of China (51378011), the National Basic Research Program of China (2011CB013800), and Tongji-Bayer Academy.

Bang, S. S., Lippert, J. J., Yerra, U., Mulukutla, S., and Ramakrishnan, V. (2010). Microbial calcite, a bio-based smart nanomaterial in concrete remediation. Int. J. Smart Nano Mater. 1, 28-39. doi: 10.1080/19475411003593451

Boquet, E., Boronat, A., and Ramos-Cormenzana, A. (1973). Production of calcite (calcium carbonate) crystals by soil bacteria is a common phenomenon. Nature 246, 527-529. doi: 10.1038/246527a0

De Muynck, W., Cox, K., De Belie, N., and Verstraete, W. (2008a). Bacterial carbonate precipitation as an alternative surface treatment for concrete. Constr. Build. Mater. 22, 875-885. doi: 10.1016/j.conbuildmat.2006.12.011

De Muynck, W., Debrouwer, D., De Belie, N., and Verstraete, W. (2008b). Bacterial carbonate precipitation improves the durability of cementitious materials. Cem. Concr. Res. 38, 1005-1014. doi: 10.1016/j.cemconres.2008. 03.005 
De Muynck, W., De Belie, N., and Verstraete, W. (2010). Microbial carbonate precipitation in construction materials: a review. Ecol. Eng. 36, 118-136. doi: 10.1016/j.ecoleng.2009.02.006

Jonkers, H. M. (2011). Healing Agent for Self-Healing Cementious Materials. Patent No: WO 2011/126361 A1.

Jonkers, H. M., Thijssen, A., Muyzer, G., Copuroglu, O., and Schlangen, E. (2010). Application of bacteria as self-healing agent for the development of sustainable concrete. Ecol. Eng. 36, 230-235. doi: 10.1016/j.ecoleng.2008.12.036

Marquardt, D. W. (1963). An algorithm for least-squares estimation of nonlinear parameters. J. Soc. Ind. Appl. Math. 11, 431-441. doi: 10.1137/0111030

Rodriguez-Navarro, C., Jimenez-Lopez, C., Rodriguez-Navarro, A., GonzalezMunoz, M. T., and Rodriguez-Gallego, M. (2007). Bacterially mediated mineralization of vaterite. Geochim. Cosmochim. Acta 71, 1197-1213. doi: 10.1016/j.gca.2006.11.031

Ruiz, C., Monteoliva-Sanchez, M., Huertas, F., and Ramos-Cormenzana, A. (1988). Calcium carbonate precipitation by several species of Myxococcus. Chemosphere 17, 835-838. doi: 10.1016/0045-6535(88)90263-9

Stocks-Fischer, S., Galinat, J. K., and Bang, S. S. (1999). Microbiological precipitation of CaCO3. Soil Biol. Biochem. 31, 1563-1571. doi: 10.1016/S00380717(99)00082-6

Van Tittelboom, K., De Belie, N., De Muynck, W., and Verstraete, W. (2010). Use of bacteria to repair cracks in concrete. Cem. Concr. Res. 40, 157-166. doi: 10.1016/j.cemconres.2009.08.025

Wang, J., Dewanckele, J., Cnudde, V., Van Vlierberghe, S., Verstraete, W., and De Belie, N. (2014a). X-ray computed tomography proof of bacterialbased self-healing in concrete. Cem. Concr. Compos. 53, 289-304. doi: 10.1016/j.cemconcomp.2014.07.014
Wang, J. Y., Soens, H., Verstraete, W., and De Belie, N. (2014b). Self-healing concrete by use of microencapsulated bacterial spores. Cem. Concr. Res. 56, 139-152. doi: 10.1016/j.cemconres.2013.11.009

Wiktor, V., and Jonkers, H. M. (2011). Quantification of crack-healing in novel bacteria-based self-healing concrete. Cem. Concr. Compos. 33, 763-770. doi: 10.1016/j.cemconcomp.2011.03.012

Wu, M., Johannesson, B., and Geiker, M. (2012). A review: self-healing in cementitious materials and engineered cementitious composite as a self-healing material. Constr. Build. Mater. 28, 571-583. doi: 10.1016/j.conbuildmat.2011.08.086

$\mathrm{Xu}, \mathrm{J}$., and Yao, W. (2014). Multiscale mechanical quantification of self-healing concrete incorporating non-ureolytic bacteria-based healing agent. Cem. Concr. Res. 64, 1-10.

Xu, J., Yao, W., and Jiang, Z. W. (2014). Non-ureolytic bacterial carbonate precipitation as a surface treatment strategy on cementitious materials. J. Mater. Civ. Eng. 26, 983-991. doi: 10.1061/(ASCE)MT.1943-5533.0000906

Conflict of Interest Statement: The authors declare that the research was conducted in the absence of any commercial or financial relationships that could be construed as a potential conflict of interest.

Copyright (c) $2015 \mathrm{Xu}, \mathrm{Du}$, Jiang and She. This is an open-access article distributed under the terms of the Creative Commons Attribution License (CC BY). The use, distribution or reproduction in other forums is permitted, provided the original author(s) or licensor are credited and that the original publication in this journal is cited, in accordance with accepted academic practice. No use, distribution or reproduction is permitted which does not comply with these terms. 